\title{
Selection Process of School Principals in Turkey and Some Other Countries: A Comparative Study
}

\author{
Sait Akbaşlı ${ }^{1}$, Mehmet Şahin ${ }^{2, *}$, Burak Gül \\ ${ }^{1}$ Faculty of Education, Hacettepe University, Turkey \\ ${ }^{2}$ Ahmet Keleşoğlu Faculty of Education, Necmettin Erbakan University, Turkey \\ ${ }^{3}$ St. Graduate School of Educational Sciences, Hacettepe University, Turkey
}

Copyright $\bigcirc 2017$ by authors, all rights reserved. Authors agree that this article remains permanently open access under the terms of the Creative Commons Attribution License 4.0 International License

\begin{abstract}
The purpose of this study is to analyze the process of school principal selection and appointment in Turkey and some other developed countries in a comparative way. The specific purpose is to make suggestions in order to improve the school principal selection process in Turkey by comparatively analyzing school principal selection process in Turkey and some developed countries. The focus is on the principal selection processes in the USA, Germany, and Finland, and it makes a comparison with the current situation implemented in Turkey. In most of the states in the USA, in order to be a principal, a certificate, a master's degree, and being an actual teacher are required. In the study methodology, official papers and documents have been analyzed in the context of research review in order to study the existing materials that do not require collecting through a data collection tool. These documents include related official reports, graduate thesis, articles, proceedings, National Education Councils conclusions, and legislative texts consisting of official regulations. The findings indicate that there are various selection methods used for this purpose. District Board of Education is in charge at selection procedures. In Germany, there is a variety of selection procedures among the states. The states' Education Ministries and administrators are in charge of selection and appointment of principals and modifications of selection procedures. The state exams and regular official performance assessments by superiors are decisive in the centralized selection process in most federal states. In Finland, a certificate and teaching qualification are required to be a principal. Interviews and tests are used in the selection procedures. Administrators and educational committee members are in charge of the highly decentralized selection process. There are some common and varied features in principal selection process between Turkey and the mentioned countries in the study. In Turkey, school principality is regarded as a secondary role to a teacher and the principal selection processes, procedures, and rules change very frequently in time.
\end{abstract}

Keywords School Principal, School Principal Selection, Educational Administrator

\section{Introduction}

Shifts in school formation and educational administration also changes roles of school principals. School principals have to train and improve themselves in order to fulfill the expectations of students, teachers, and parents and to improve school productivity [1]. In developed countries, principal candidates are trained not to acquire traditional management skills but to acquire leadership skills [2]. School principals have responsibility in improving school quality so that importance of training of them is emphasized especially in these countries [3]. With gradually increasing expectations, principals should not only be well trained but also their selection and appointment criteria are required to be based on professional knowledge and skills necessary for success in the administrative processes [4]. In Turkey, policies and practices of the training and selection of school principals should be reviewed and goal-oriented work is needed to be implemented in order to improve educational quality [5].

According to Recepoğlu and Kılınç [6], there have been four main tendencies in training school principals, which are apprenticeship, educational sciences, supplementary criteria, and arbitrariness. In this paper, authors state that arbitrariness era started by a regulation that dictates oral examination in principal selection and training process. Recently, in Turkey, almost each year, a regulation concerning principal selection and training has been put into practice. These regulations aim to eliminate the problems about principal selection and training. Some of the regulations addressed National Education Council's goals while others are not related to them. Stakeholders have considered some of the implementations positive while some of them have been highly criticized negatively. 
Aforementioned situations, putting new regulations into practice each year, changes made to items of these regulations and critics made about the implementations indicate that principal selection procedures have no standards, and the policies concerning principal selection are not certain in Turkey.

Therefore, in this general problem of the research, the following questions have been raised and analyzed:

- What is the current situation in Turkey?

- Are there frequently changing principal selection processes?

- What are the different aspects in other countries?

- What kind of progress has been made in Turkey?

This study aims to make suggestions in order to improve the school principal selection process in Turkey by comparatively analyzing school principal selection process in Turkey and some developed countries. It also wants to emphasize weak and strong points of the process in Turkey. This study is important because it covers most recent situation and school principal selection process changes very frequently in Turkey.

\section{Method}

In the study, official papers and documents have been analyzed in the context of research review in order to study the existing materials that do not require collecting through a data collection tool. The selected documents have been compatible with the research topic. These documents include related official reports, graduate thesis, articles, proceedings, National Education Councils conclusions, and legislative texts consisting of official regulations.

In this study, the USA, Germany and Finland have been selected with the maximum variation sampling method of purposive sampling to compare with Turkey. In the purposive sampling, the researcher uses his or her own judgment on the selection of the sample elements and determines them to be the most suitable ones for the research purposes [7]. The aim of maximum variation sampling method is not the generalization of the sample to population, but of presenting similarities among the diversity creating situations [8]. Using this method, these countries have been determined to provide sufficient diverse and information-rich cases to conduct in-depth research in accordance with the problem. Many reasons have been taken into consideration in the selection of these countries. Among these reasons is the fact that Germany is close to Turkey as the population size while the population of the United States is massive, and the population of Finland is very small. The education and management structures are different from each other. All of the countries are in PISA. Especially Finland and Germany are in the top ranks as some successful European countries in the PISA rankings. The United States spends huge amounts of money on education, and it is a foreign country to where the largest numbers of Turkish students go for a graduate study.

\section{Research Design}

This study has been carried out in qualitative research design based on the analysis of official papers and documents. Qualitative research enables the presentation of research results based on codes and categories by reading individual data [9]. In this context, it has been decided that the most appropriate research method is the qualitative research method for determining the principles to be assigned to the educational institutions and for the in-depth examination and interpretation of the sample applications. The research data were collected by analyzing documents. A document review includes an analysis of written materials that contain information about the cases or phenomena targeted to be investigated. Welding examination enables the analysis of a research problem based on documents produced within a certain period or based on a wide range of documents produced by different sources and in different periods [9-11]. Mainly, the official regulations about the administrators to be assigned to the Education Institutions affiliated to the Ministry of National Education (MoNE) between 2007 and 2017 and the legal documents used for the administrative appointment to the education institutions in USA, Germany, and Finland have been selected and analyzed.

\section{Data Collection and Analysis}

The legislation of the MoNE has been monitored and examined and the results related with the appointment of administrators in the educational institutions have constituted the main body of the legal regulations between April 2008 and April 2017. The content of the study is also included in the survey, which sample level, with which purposes and the main results are achieved when the content analysis is done.

Content analyzes of the legal texts reached by using mixed method have been carried out. In qualitative studies, content analysis is used in the analysis of documents [9]. Content analysis is a form of interpretation that provides a quantitative and accurate generalization for structuring and classifying meaningful meanings in order to reveal the common aspects of many textual contents [12]. The basic process in content analysis is to bring together similar data within the framework of certain concepts and themes and to interpret it in a form that readers can understand [10]. Conducting content analysis requires selection-reduction, grouping, generalization-abstraction, and tracking of the association with theory $[12,13]$. In this study, the content analysis of the data follows the following steps.

In the selection-reduction phase, a certain sample was selected from the research universe and their contents were tried to be placed in the category system, which was 
formed in accordance with the research purposes. While establishing the principles of appointing the study's study universe to the administrators in selected countries in Turkey and the world, it sets legal sample of the sample for the administrators of the education institutions for Turkey between 1994-2017 and the educational institutions in America, Germany and Finland countries. Then, legislative texts to be examined after the research sample was identified at the grouping stage were tried to be placed in the categorization system. In addition, in legislative texts examined during the generalization-abstraction phase, the meanings in question have been tried to be merged and generalized. Finally, in connection with the theory, the possible legal reasons for the assignment of officials to the educational institutions in Turkey and selected countries were put under discussion by going through the examined legislative texts.

\section{Truth and Reliability}

The ability to provide truth in content analysis depends on the consistency between the objectives and tools of the research [12-14]. In content analysis, there are no truth measurement tools other than definitions of categories. For this reason, in content analysis, the definitions of categories should be publicly identifiable and well defined. Reliability is provided especially by the coding method and the categorizing technique. The most important sign of reliability in this context is the creation of the categories and the explicit identification of each category [11-12]. In order to ensure the truth and reliability of this research carried out in this context, the categories were determined based on the theoretical structure. The researchers independent of one another made the categories and encodings created in the data analysis process, and then the generated codes and categories were compared for reliability.

\section{Findings}

\section{Selection of School Administrators in Turkey}

Recent developments in school principal selection in Turkey are based on National Education Councils and regulations, which dictate how to implement the procedures. In Turkey, National Education Councils are the highest advisory body in which solutions to problems are presented, advisory decisions are made, and policy is developed about educational issues. The last National Education Council (19th National Education Council) was held in 2014, the previous meeting (18 ${ }^{\text {th }}$ National Education Council) was held in 2010. Difference between decisions taken in these two councils shows us the way of change.

In the $18^{\text {th }}$ National Education Council, some of the decisions taken about the training and selection of school principal are determined. In this context, graduate study should be considered in principal appointment. Incumbent school principals should be provided to complete graduate study for their personal development. Necessary arrangements should be made to appoint school principal who is a leader and able to create school culture. School principals should be provided with transformational leadership abilities for institutional transformation. The tenure of school principals should be longer to ensure fulfilling goals. Professional qualifications should be considered to be developed on the basis of alternative selection methods such as portfolio and process evaluation in school administrator selection process. Reorganization of schools is necessary in academic and administrative aspects. Demonstration of ethical leadership behavior by the school administrator is necessary. As a leader, school administrator should be provided with more space and more authority.

In the 19th National Education Council, the issue of educational administration was extensively mentioned. Educational administrators' qualifications, appointment of them for the first time and their re-assignment and training in service areas were included. The decisions taken in the Council can be summarized here. Among the selection criteria of the educational administrator candidates, it is necessary to have a bachelor's degree, to be successful in the central written examination, to be a vice principal to be able to be selected as principal, and to have appropriate teaching branch for the relevant school. Graduate study in the field of educational administration and Educational Administration Competency Certificate from the National Educational Administration Competency Program structured at the national level should be reasons for preference. Appointments by interview commissions and establishment of educational administrator training centers are necessary. Duration of school administration should be limited by the time. Vice principals' appointments by principal opinion should be a priority. Being a teacher for a certain period of time and achieving a central examination are required to be a vice principal. Being vice principal for a certain period is required to be principal, also. Objective, measurable, distinctive criteria must be used in reassignment. Evaluation commission must have worked with the principal for at least one year and the school performance as well as perception measurement should be taken into consideration. School budgets should be created and legal guarantees and opportunities must be provided for effective use.

Among the decisions taken in these two councils, here are the following differences. Although there was much emphasis on the leadership of the administrators in the $18^{\text {th }}$ Council, there was no mention of it in the $19^{\text {th }}$ Council. In the $18^{\text {th }}$ Council, administrators' appointments for a longer duration to reach the targets were suggested while limited duration was suggested in the $19^{\text {th }}$ Council. In the $18^{\text {th }}$ Council using 
alternative methods in selection of school administrator was proposed while in the $19^{\text {th }}$ promoting in a hierarchical way in administrative steps and principal's rights in selection of vice principals was proposed. What is more, in the $18^{\text {th }}$ Council more authority was given to the school administrator, while in the $19^{\text {th }}$ Council creation of budget for the school and use of it by administration was suggested.

The implementations of the Ministry of Education's selection and appointment of school administrators are based on regulations. There are a number of legislative arrangements made in recent years regarding the appointment of educational administrators in Turkey. When looking at the release dates of regulations for appointment of administrators, it is a matter of fact that a new legislation is being regulated nearly each year (Table 1). Frequent changes indicate that the administrator selection and training process has not reach to a certain standard. It cannot be said that the changes in the implementation of the school administrator selection in Turkey reflect the development over time [15].

The regulation in force for the appointment of administrators of educational institutions in Turkey (Regulation on the Appointments of the Administrators of Educational Institutions of the MoNE) was published in the official gazette on 22/04/2017. It was implemented after $19^{\text {th }}$ National Education Council. According to the regulation definition of the administrator covers principal, deputy vice principal and vice principal. It is stated that in the above regulations, administrative duties are given as second duty. On the other hand, in the last two regulations, unlike the previous ones, it is stated that assignment is made rather than appointment after selection, that is, administrators will be assigned for certain periods. According to the "Regulation on the Appointments of the Administrators of Educational Institutions of the MoNE," which was put into force on 20/04/2017, the following conditions are required to be assigned as school administrators: being a graduate of a higher education institution, being a teacher at the Ministry of National Education, being able to be appointed as a teacher in the school to be assigned as principal, Not being dismissed from the administrative post within the last four years because of a judicial or administrative investigation result, and being completed, deferred or exempted from compulsory labor obligations.

Apart from the general conditions above, there are also special requirements for the principal post and other administrative posts: To become a school principal, it is subject to the condition that administrator must have had the administrative experience before in different period according to the title. Similarly, in order to be appointed as deputy vice principal and vice principal it is required to work in administrative positions or have at least four years of teaching experience. Under these circumstances, teachers are prevented from applying to principal positions. Now, it is only possible to rise sequentially in the administrative steps. One another important issue is that oral examinations and assessments will be used to appoint the school principal, while the results of the written examinations will be used for the appointment of deputy vice principal and vice principal.

The previous regulation before the current one was issued before the $19^{\text {th }}$ National Education Council. In this regulation dated 06/10/2014, all administrator candidates were assessed by oral exam results without considering positions. According to this regulation, in order to be a principal, it was necessary to work for a certain period in administrative positions or work as a teacher at least eight years. Therefore, teachers could apply to the principal positions if they had completed the term. Prior to this date, while the administrative task was a permanent task, under the new regulation, administrators will not be able to work more than 8 years in the same institution and it is made compulsory to re-apply to be reappointed for the duty requested. According to this regulation, the only method applied in evaluation of the administrator selection process is the oral evaluation, and the written exam, which was before, would not be conducted. According to Plenary Session of Administrative Law Divisions of the Council of State (2014), this regulation was not in compliance with the law in particular with regard to the appointment of vice deputy principal and deputy principal. In their study, Arabac1 et al. [16] stated that supervisors, union representatives and school administrators who participated in criticized this regulation in many ways. Later, MoNE started implementation of written examination for vice principal positions with the current regulation dated 10/06/2015.

Table 1. Regulations

\begin{tabular}{|c|l|}
\hline Date & \multicolumn{1}{|c|}{ Regulation } \\
\hline $22 / 04 / 2017$ & $\begin{array}{l}\text { Appointments of the Administrators of Educational } \\
\text { Institutions of the Ministry of National Education }\end{array}$ \\
\hline $10 / 06 / 2015$ & $\begin{array}{l}\text { Appointments of the Administrators of Educational } \\
\text { Institutions of the Ministry of National Education }\end{array}$ \\
\hline $06 / 10 / 2014$ & $\begin{array}{l}\text { Appointments and Relocation of the Administrators of } \\
\text { Educational Institutions of the Ministry of National } \\
\text { Education }\end{array}$ \\
\hline $08 / 04 / 2013$ & $\begin{array}{l}\text { Appointments and Relocation of the Administrators of } \\
\text { Educational Institutions of the Ministry of National } \\
\text { Education }\end{array}$ \\
\hline $02 / 28 / 2013$ & $\begin{array}{l}\text { Appointments and Relocation of the Administrators of } \\
\text { Educational Institutions of the Ministry of National } \\
\text { Education }\end{array}$ \\
\hline $08 / 13 / 2009$ & $\begin{array}{l}\text { Appointments and Relocation of the Administrators of } \\
\text { Educational Institutions of the Ministry of National } \\
\text { Education }\end{array}$ \\
\hline $04 / 24 / 2008$ & $\begin{array}{l}\text { Administrators of Educational Institutions of the Ministry } \\
\text { of National Education }\end{array}$ \\
\hline
\end{tabular}

\section{The School Principal Selection in Other Countries}

School administration is not perceived as a profession around the World. So, training of school principals as professionals are not widespread well [15]. There are more schools than factories around the World. Despite that, there 
are far more efforts to train business administrators than school principals. The USA has extensive experience and knowledge in this area while no important fundamental policy about training of school principals has been created in Turkey [2]. Therefore, importance of school principal training has been emphasized strongly in developed countries recently [17]. Generally, school administrative boards, multi-member committees, or leading officials decide the selection of school principals. In some countries, there are administrative boards or committees, which are responsible for running the school and that they are authorized to decide school principal. In some other countries, like Germany, schools' own administration has no right to decide on the assignment of the principals. There are strictly regulated selection processes in those countries [18]. In many European countries, in order to be appointed as a school principal, professional teaching experience and special training is required [19]. To have deeper understanding, process of school principal selection in the U.S., Germany and Finland are analyzed in details below.

\section{School Principal Selection in the USA}

The USA has long past in training school principals and it can be stated that the country is a pioneer in this topic [15]. The country is composed of many states and there is no central ministry of education. States are in charge of educational issues and school authorities are located under local administrations [15]. The states are divided into educational districts in which there are "District Educational Administrator" and "District Educational Board" in charge of education.

In order to be a school principal in the USA, most states require having Master's degree in educational administration [3]. School principals have to complete educational faculty and have teaching experience in most of the states [22]. Principal candidates are required to have a certificate on school administration. In order to get this certificate, generally, three years of teaching experience, completion of principal training program and passing a license examination accepted by state are required [21,22]. Moreover, the candidates must meet other conditions set by educational board [15].

The application process to be the school principal begins by publishing vacant administrator positions of the educational district. Principal candidates apply to the educational district for these positions. The selection method varies between states and educational districts, but usually takes place in the form of a questionnaire or test, a recommendation letter from the previous schools or the university that the candidate has graduated from, the evaluation of the license document, and an interview. In this way, it is tried to be determined whether the candidate will be able to satisfy the needs with his / her experience and qualifications. As a result of evaluations, the District
Educational Board selects the school principal among the applicants [22]. The selected school principal is appointed to post for a certain period. For continuity, the school principal must constantly follow new developments in the field and renew and improve herself/himself [23, 24].

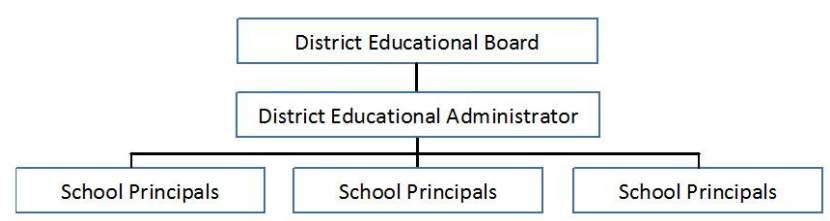

Figure 1. Organization of Educational District in the U.S.A. Aykut, $2006[22]$

\section{Selection of School Administrators in Germany}

In Germany, each state has its own legislation on education. Therefore, school administrator selection and appointment procedures are based on their own laws. In all the states, principals are employed as civil servants and generally, they have lifelong tenure. Therefore, it is a permanent job. Thus, if appointment is made, the principal may continue in this position until retirement. Ministries of Education and officials are not only responsible for selection and appointment processes, but also for the development of these selection methods. Filling vacancies requires long-term staff planning for the authorities. For this reason, the creation of a candidate's pool has been considered suitable for successful selection and assignment [25].

In order to be a school principal, candidates are required to be qualified as a teacher in the relevant school form, have at least a bachelor's degree, and have experience for 3-5 years [18]. Qualifications like being vice-principal or team leader and involving in teacher training is advantage. Nevertheless, regular formal evaluations of higher administrators and state examinations after teacher training are decisive mostly [24]. While oral examinations are conducted in each state, written exams are conducted in some states [15]. There is no nationwide common selection procedure in Germany. It varies according to the states [24-26]. Selection methods include regular formal assessments, interviews, classroom observations, and personal presentation of the candidate. At the end of the assessments, the most appropriate candidates are appointed as school principals [25].

\section{Selection of School Administrators in Finland}

In this country, the social status of school principals is perceived highly important. It is thought that what they do is very important. However, it has become increasingly difficult to appoint a school principal recently. According to the educational levels of the schools, the duties of the administrators are changing and depending on these levels, the hiring techniques of them are changing [27]. In Finland, school principal candidates must be qualified to teach in 
the schools where they apply. Candidates must have a Certificate in Educational Administration or they must have completed an educational leadership university program that includes 25- credit Certificate in Educational Administration. Although there is no specific criteria for work experience, principals selected for permanent post required to have experience in administration in practice. Not only is it necessary for the principals to have at least Master's degree but also teaching qualification. As a rule, selected principals are among experienced teachers [18].

In schools attached to municipalities in Finland, principal selection process operates like this: vacant position is opened by the board of directors in charge of education after announcing the retirement or separation of any reason of the present principal. Administration advertises the vacant position at least in the regional main gazette, in the national teacher magazine, or on the job center website. Applications will be accepted within a certain period. Subsequently, the applications are compared by at least by administrators, and, in some cases, the chairperson of the school board, education board members, or the whole board conducts this process [28]. According to Tihveräinen [28], the selection process can be briefly summarized like this: A decision is made to open a principal's position, an advertisement is made, applications are ranked upon applicants' educational experience and level of education, interviews held by education administrators (interview group), and the group tries to make a decision on the most suitable candidate.

In comparing candidates, it has become increasingly common to use psychological tests in addition to interviews. Principals are appointed to their tasks for a six-month trial period [18]. The localized model in Finland appears to be more effective than the centralized models because governing body knows the needs best and the parents, teachers and other parties can be consulted in case of a selection decision.

\section{Conclusions and Suggestions}

The purpose of this study is to find out the selection process of principals for schools, specifically the current situation in Turkey, frequently changing principal selection processes, the different aspects in other countries and the kind of progress that has been made in Turkey.

Many decisions about the qualifications and appointments of the educational administrators in Turkey have been made up in the National Education Councils. Some of them have been put into practice in accordance with the regulations and some not. No standards have been set for school administrators' selection in Turkey [3]. This situation manifests itself in frequently changing regulations. On the other hand, it has been found that all the examined countries implement various alternative selection methods during the selection process. In Turkey, arrangements on selection process and selection methods are determined in regulations and cannot be ruled out in practice.

Authorization and responsibility in the process of principal selection and appointment have been delegated to local authorities particularly in Finland and in the USA. In Germany, the states exercise this power. In Turkey, whole process is determined entirely by the central authority. It is stated that the process is more effective in Finland as parents, teachers and other party counselors are available when a selection decision is made. In Turkey, the interview commissions in the last two regulations allow at least some officials from the provincial organization to participate in the selection process. Although this situation resembles similar cases abroad, it has become an important point of criticism in our country.

In the countries searched in this study, it is compulsory to be a part of teaching profession in order to become a principal. This is the case in Turkey, too. However, with the last regulation, in order to become a principal, firstly, it is stipulated to have worked as vice-principal or in other administrative positions. This situation can be interpreted as a good implementation in improving the quality of administrators in the educational system. In fact, along with this implementation, the last National Educational Council's recommendation on the selection of principals among the vice-principals has been fulfilled.

In the USA and Finland, having Master's degree is a requirement for the principal. Obtaining a certificate of school administration is another requirement in the United States and Finland. In the USA, the candidate must have completed education faculty. It is not compulsory to be a graduate of education faculty or having Master's degree or having any certificate to apply to the school principal post in Turkey.

Principals who have been successful at the end of the selection process are permanently appointed in Germany while they are appointed for a certain period in the United States and Finland. Similarly, in Turkey, the procedure of permanent appointment has been terminated with the last two regulations. It is emphasized that teaching is primary occupation. On this occasion, a solution to the negative criticism, that is, a principal appointed to a school for once would stay there for a lifetime without improving herself or himself and without striving and making effort for the school was created.

The following recommendations can be made regarding the selection process of the school administrators in Turkey by evaluating the above results:

- As stated in the 18th National Education Council, besides alternative methods such as portfolio and process evaluation, professional qualifications should be taken into consideration.

- In the $18^{\text {th }}$ National Education Council, there was emphasis on the qualifications that school administrators should possess while in the $19^{\text {th }}$ National Education Council there were no decisions related to this issue. However, since it is assumed that 
the school administrator will also be the leader of the school, it is necessary that the selection criteria and methods be rearranged to determine the leadership qualities.

- Stakeholder opinions should be included when determining the appointment criteria. This means that the process should be carried out with more objective and acceptable criteria.

- $\quad$ School administrators should be encouraged to study at graduate level.

- School administrators should be provided with administrative training programs prior to their posts, so that professional standardization and institutionalization should be provided.

- In accordance with the above mentioned points, there should be arrangements in the Regulation on the Appointments of the Administrators of Educational Institutions.

\section{REFERENCES}

[1] Akbaşlı, S., Balıkçı, A. (2013). Okul Yöneticisi ve Öğretmen Görüşlerine Göre Okul Yöneticiliğinin Meslekleșmesinin Değerlendirilmesi (Evaluation of Professionalisation of School Administration According to The School Administrators and Teacher Perceptions). Mersin Üniversitesi Eğitim Fakültesi Dergisi, 9(2), 366-377.

[2] Çelik, V. (2002). Ĕ̈itim Yöneticisi Yetiştirme Politikasına Yön Veren Eğilimler. 21. Yüzyıl Eğitim Yöneticilerinin Yetiştirilmesi Sempozyumu. Ankara, 16-17 Mayıs 2002.

[3] Şişman, M., Turan, S. (2002). Dünyada Ĕ̌itim Yöneticilerinin Yetiştirilmesine İlişkin Başlıca Yönelimler ve Türkiye İçin Çıkarılabilecek Bazı Sonuçlar. 21. Yüzyıl Eğitim Yöneticilerinin Yetiştirilmesi Sempozyumu. Ankara, 16-17 Mayıs 2002.

[4] Özmen, F., Kömürlü, F. (2010). Eğitim Örgütlerine Yönetici Seçme ve Atamada Yaşanan Sorunlar ve Yönetici Görüşleri Temelinde Çözüm Önerileri (The Problems Occur In Selection and Appointment of Administrator in Education Organizations and Solution Proposals On The Basis Of Managers' Views). Sosyal ve Beşer Bilimler Dergisi, 2(1), 25-33.

[5] Aktepe, V. (2014). Okul Yöneticilerinin Seçme ve Yetiştirme Uygulamalarına Yönelik Öğretmen ve Yönetici Görüşleri (Ideas of Educators about Application of National Education Ministry on Choosing and Growing School Administrators). Turkish Studies - International Periodical for the Languages, Literature and History of Turkish or Turkic, 9(2), 89-105.

[6] Recepoğlu, E., Kılınç, A.Ç. (2014). Türkiye'de Okul Yöneticilerinin Seçilmesi ve Yetiştirilmesi, Mevcut Sorunlar ve Çözüm Önerileri (Raising and Selecting School Administrators in Turkey, Present Problems and Solutions). Turkish Studies - International Periodical for the Languages, Literature and History of Turkish or Turkic, 9(2), 1817-1845.
[7] Balc1, A. (2005). Sosyal Bilimlerde Araștırma. Ankara: PegemA Yayıncilik

[8] Şişman, M., Turan, S. (2004). Dünyada Eğitim Yöneticilerinin Yetiștirilmesine İlișkin Başlica Yönelimler ve Türkiye İçin Çıkarılabilecek Bazı Sonuçlar. Türk Ĕgitim Bilimleri Dergisi, 2(1), 13-26.

[9] Merriam, S. (1998). Qualitative research and case study applications in education. Revised and expanded from case study research in education. USA: JB Printing.

[10] Yıldırım, A., Şimşek, H. (2005). Sosyal Bilimlerde Nitel Araştırma Yöntemleri. Ankara: Seçkin Yayıncılık

[11] Karadağ, R. (2014). Okuma İlgisi, Tutumları ve Alışkanlığı Konusunda Yapılmış Çalışmaların Lisansüstü Tezlere Dayalı Analizi: YÖK ve ProQuest Veri Tabanları Örneklemi (Analysis of the Graduate Theses in the Field of Reading Interest, Attitudes and Habits: The Sample of YOK and ProQuest Databases), Pamukkale Üniversitesi Eğitim Fakültesi Dergisi, Sayı 35 (Ocak 2014/I), ss. 1-17

[12] Gökçe, O. (2006) İçerik analizi: Kuramsal ve pratik bilgiler. Ankara: Siyasal Kitabevi.

[13] Fruh, W. (2001). Inhaltsanalyse. Theorie und praxis. 5., Uberarbeitete Auflage, Konstanz: UVK.

[14] Bilgin, N. (2006). Sosyal bilimlerde içerik Teknikler ve örnek çalışmalar. Ankara: Siyasal Kitabevi.

[15] Akın, U. (2012). Okul Yöneticilerinin Seçimi ve Yetiştirilmesi: Türkiye ve Seçilmiş Ülkelerden Farklı Uygulamalar, Karşılaştırmalar (Selection and Training of School Administrators: Different Applications in Turkey and Selected Countries' Comparisons). AİBÜ Sosyal Bilimler Enstitüsü Dergisi, 12(2), 1-30.

[16] Arabac1, B. A. Şanl1, Ö., Altun, M. (2015). Okul Yöneticilerinin Yetiştirilme ve Atama Yöntemlerine İlişkin Sendika Temsilcilerinin, Maarif Müfettişlerinin ve Okul Yöneticilerinin Görüşlerinin Değerlendirilmesi Evaluation of the Views Related To Methods of Training and Assigning School Administrators of Union Representatives, Education Inspectors and School Administrators). Mustafa Kemal Üniversitesi Sosyal Bilimler Enstitüsü Dergisi, 12(31), 166-186.

[17] Özmen, F. (2002). Okul Müdürlerinin Yetiştirilmesi-Gelişmiş Ülkelerdeki Uygulamalardan Örnekler. 21.Yüzyıl Eğitim Yöneticilerinin Yetiştirilmesi Sempozyumu. Ankara, 16-17 Mayıs 2002.

[18] Taipale, A. (2012). International Survey on Educational Leadership A survey on School Leader's Work and Continuing Education. Finnish National Board of Education. [from http://www.oph.fi/download/143319_International_survey_ on_educational_leadership.PDF], on 13.11.2015

[19] Eurydice (2013). Key Data on Teachers and School Leaders in Europe 2013 Edition. [from http://eacea.ec.europa.eu/education/eurydice/documents/ke y_data_series/151en.pdf], on 20.11.2015

[20] Balyer, A., Gündüz, Y. (2011). Değişik Ülkelerde Okul Müdürlerinin Yetiştirilmesi: Türk Eğitim Sistemi İçin Bir Model Önerisi (Training School Principals in Different Countries: A New Model Proposal for the Turkish Educational System). Kuramsal Eğitimbilim, 4(2), 182-197. 
[21] Jennings L. L. Wagoner. Review of Guthrie, James W., ed., Encyclopedia of Education. H-Education, H-Net Reviews. August, 2003. URL:

http://www.h-net.org/reviews/showrev.php?id=8045

[22] Aykut, C. M. (2006). Türkiye ve A.B.D.’de Yöneticilerinin Yetiştirilmesinin Karş1laştırılması Comparison of the School Administrators' Training Activities in Turkey and the USA). Yüksek Lisans Tezi. Dokuz Eylül Üniversitesi.

[23] Arslan, H. (2002). Okul Müdürlüğünü Geliştirme Programları (Programs for School Principals' Improvement). 21.Yüzyıl Eğitim Yöneticilerinin Yetiştirilmesi Sempozyumu. Ankara, 16-17 Mayıs 2002.

[24] Balyer, A., Gündüz, Y. (2011). Değișik Ülkelerde Okul Müdürlerinin Yetiştirilmesi: Türk Eğitim Sistemi İçin Bir Model Önerisi (Training School Principals in Different Countries: A New Model Proposal for the Turkish Educational System). Kuramsal Eğitimbilim, 4(2), 182-197.
[25] Huber, S.G., Hiltman, M. (2010). The Recruitment and Selection of School Leaders-First Findings of an International Comparison. S.G. Huber (Ed.). School Leadership-International Perspectives, 303-330. Springer.

[26] Rosenbusch, N., Rauch, A. and Bausch, A. (2013), “The mediating role of entrepreneurial orientation in the task environment-performance relationship: a meta-analysis", Journal of Management, Vol. 39, No. 3, pp. 633-659.

[27] Ministry of Education (2007). Improving School Leadership, Finland. Country Background Report. [from http://www.oecd.org/finland/38529249.pdf], on 20.11.2015

[28] Tihveräinen, S. (2009). Principal Selection Process in Eight Finnish Municipalities. Master's Thesis. Jyväskylä University, Finland. [from https://jyx.jyu.fi/dspace/bitstream/handle/123456789/20284 /URN_NBN_fi_jyu-200905231614.pdf? Sequence=1], on 20.11 .2015 . 